those on the charter could be guaranteed to produce some noisy arguments - rather more than you hear today. Someone once calculated that I wrote the equivalent of 10 novels reporting those debates. That's probably not far out.

Annual meetings will not be the same without the neat figure of Lawrie Wootton bustling around, checking speakers' names, borrowing their notes, or confirming a phrase. Certainly the $B M \mathcal{F}$ will miss his substantial and accurate contributions, which more than fulfilled Hugh Clegg's demand that "if speakers are going to be bloody fools I want the profession to see."

\title{
The royal colleges golf club, 1890-1990
}

\author{
J A Savin
}

The friendly rivalry between its royal colleges has added spice to Edinburgh medicine for hundreds of years. Both are old, but the physicians know that their royal college was founded first, in 1681 , despite the surgeons doing all they could to block the granting of a royal charter. The Royal College of Surgeons came into being a quarter of a century later, but its fellows see it as the senior organisation - the continuation of a city guild of barber surgeons set up in 1505. This difference of view matters only when both presidents attend the same royal function; the problem of precedence baffled the heralds and the courts for a long time before they decided in favour of the physicians.

In 1890 the Royal Colleges Golf Club was formed. Its first captain was Douglas Argyll Robertson, an ophthalmic surgeon whose work on the eye changes in syphilis is still known to every doctor in the world (fig 1). He was a fine golfer, and his obituary tells us that his wife's most cherished necklace was formed of the numerous gold medals he had won at the sport. Ninety fellows paid a guinea each for a trophy to be kept by the winning college for one year. The club was a success and the match has been played in East Lothian each May since then, with short pauses for world wars only. An official recorder watches the day's events and reports on them at the dinner a year later.

An outsider would see only groups of drab Edinbourgoisie trudging round a golf course: recorders have to see much more and to bathe events in a warm surrealistic glow. Fifty such reports are held by the club and the following extracts may help to pass on the flavour of these meetings. Readers are warned that recorders are not tied down by the exact truth and have been known to lean a little towards their own side.

\section{Battle of status symbols}

When the great day dawns members of the club leave for Luffness confident that juniors will "cover their absence with a skill derived from frequent practice." The battle of the status symbols begins on the roads. Once the surgeons had the bulgier cars. Then the tide turned and in 1957 "the chauffeur-driven limousines of the physicians were followed at a discrete distance by the second-hand tumbrils of the surgeons, who were obviously elated to park in such distinguished company." Sheltered parking spaces have been in demand since 1951 when a drive from the first tee "bagged a gynaecological Bentley and an orthopaedic Super-Snipe before coming to rest under a medical A40." Nowadays, of course, members of both colleges drive small family saloons.

Traditionally the weather is fine. "The sun shone, the birds sang, and a gentle east wind made ideal conditions," chirruped one recorder. An occasional squall is allowed, often blowing up "without even a call of "fore' from the Almighty." Less often "the Edinburgh, Edinburgh EH3 9YW

J A Savin, MD, consultant dermatologist flamboyant sweaters, the esoteric shirts and poly-

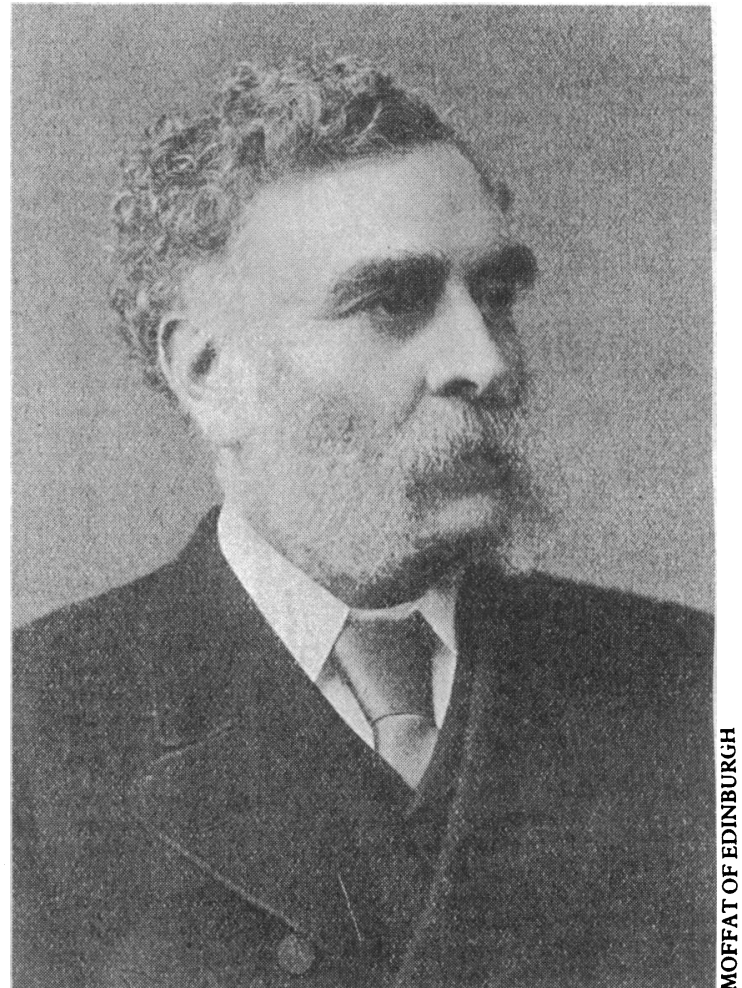

FIG 1-The golf club's first captain, Mr Douglas Argyll Robertson

chromatic pants, dear to the hearts of the highly handicapped, are hidden under windjammers and rubber breeks." Then "the drabness is only relieved by nasal azure and auricular rouge."

Recorders often comment on members' clothing which can range from "immaculate consulting attire" to "a blue jersey borrowed from some obese fisherman." Surgeons have a penchant for "pus-coloured caps": physicians for those with "just a suspicion of a button at their central points." One gamesman was said to have a tame moth which he had trained to fly out of his socks as proof of his lack of practice. Perhaps the most mysterious garment was a set of plus fours of Swiss manufacture: "The main talking point was the three zip fasteners which ensured that all things were possible, and in any direction."

Tastes also diverge over equipment, but all have a healthy respect for their golf balls, having found out over the years why "a small round object is part of the armamentarium of the hypnotist." Physicians go for "collections of cleeks, jiggers and similar apparatus with curved hickory shafts protruding at all angles from narrow tubes of rotted canvas." One used a cleek so ancient that "its face had launched a thousand chips." A scientifically minded physician "employed Dettol to inhibit the growth of fungus on his golf club grips before his annual game." Surgeons naturally 
FIG 2-The drabness is only relieved by nasal azure and auricular rouge

FIG 3-The growth of fungus on his golf club grips

FIG 4-Members had used human caddies to carry their clubs

FIG 5-One member who had "dwelt long in the rough" FIG 6-Those who cut rather than putt for dough

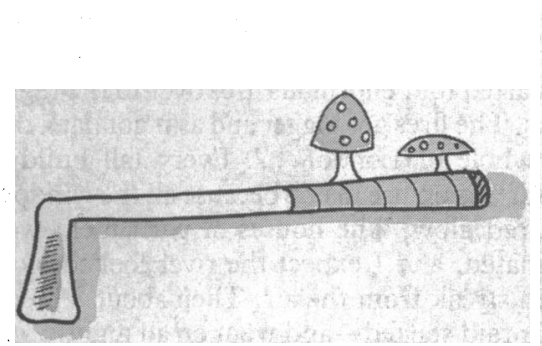

FIG 3
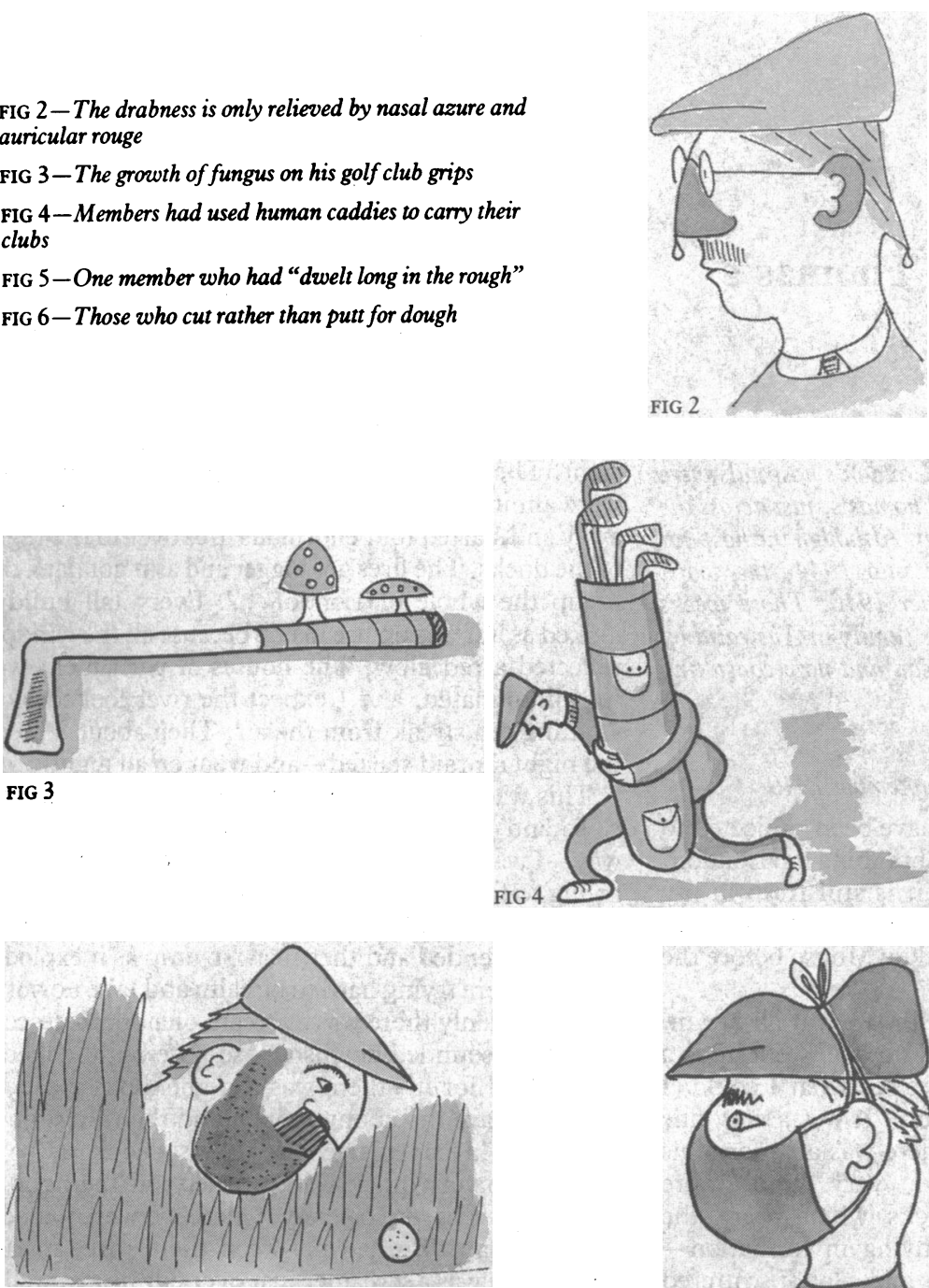

FIG 5

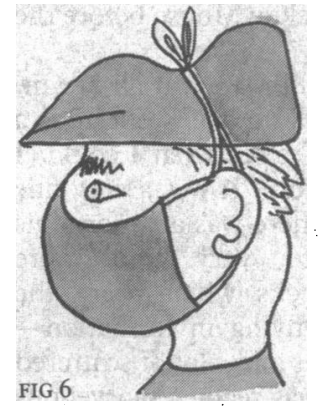

prefer "massive sets of stainless steel instruments requiring two-wheel trolley propulsion."

\section{Caddies' advice}

Until 1950, when these trolleys first arrived, members had used human caddies to carry their clubs and to deflate their egos. A hefty surgeon sadly surveying his largest divot was brusquely told to "tak' it home and practise on it." One member who had "dwellt long in the rough"' heard his caddy mutter "It's a ferret he's needing no' a caddy." Another, finding his ball in a rut on the road crossing the 15th fairway, tried to ignore his caddy's bright suggestion to avoid a penalty lift: "Pee on it and ca' it casual watter."

Machines can't mutter, and soon more "wheelbarrow-like contraptions were being dragged around by members." The most conservative sniggered when "a surgeon's trolley joined him in a sandtrap at the fifteenth and then upset. His Calvinistic partner added 13 strokes to his score for grounding his clubs in a bunker."

The morning round is played for individual trophies and scoring is often high because of the "tiresome restriction that all putts have to be holed." A feeling has grown up "that the surgeons should pay more for their round, as they tend to cut up the course." One mighty surgeon "made a Battle's incision on the first tee, which the Luffness committee subsequently decided would be suitable for planting a tree."

Recorders are sparing with their praise but one player's routine before playing his shot was seen as being "no simple waggle this, but a glorious gluteal symphony of motion in which the allure of the HulaHula merges imperceptibly with the more erotic form of the Nigerian twist to produce a sensuous whole - the despair of an Anton Dolin, the vindication of a Wolfenden." Others are less elegant: "Even when he reached the green he experienced considerable difficulties in putting since half the ball was hidden from view by the intervening adipose curtain of his abdomen." Another member performed "strange fertility rites in the rough, waving his club like a magic wand and thereby assisting in the wind-pollination of the East Lothian flora."

Next comes that part of the day, possibly the most pleasant, when weary members play the 19th hole, where "the rabbit meets the lion, unafraid." Most obey Timothy's maxim to "drink no longer water but use a little wine for thy stomach's sake," but supply their own medical excuses. Surgeons like to "arrange their own anaesthesia" or "use alcohol to achieve inner cleanliness and sterilization of the gut." The few psychiatrists present, like Bernard Shaw, drink "only to make other people more interesting." The physicians see lunch as "a pleasant test of kidney function."

All ply their opponents for the afternoon match with the "wine that maketh glad the hearts of all men" and the meal is usually a cheerful affair, accompanied by "much light badinage that so often conceals a sorrowful heart and a wounded vanity." After lunch members may rest a little before the "battle earnest" fought between "the barbers and the leeches," otherwise known as the "pedlars of pills and those who cut rather than putt for dough."

\section{Friendly rivalry indeed}

More often than not the surgeons' "pitiless manual dexterity proves too much for the weaker physicians' $z$ freely acknowledged mental skills." What else can be expected from those "accustomed to spending many hours in manipulating steel instruments in bunker-like cavities?" The "rosy and well-groomed" surgeons enjoy thrashing the physicians "sicklied o'er by the pale cast of thought." Friendly banter may cause cracks to appear in a member's "brittle gentlemanly veneer." One successful competitor, long before Trevino, was "able to use his vocal cords right up to the moment of impact": an unsuccessful one had a grumpy partner who was "the reverse of a ventriloquist in that he said nothing, but his lips moved." Tougher measures have been discouraged since 1974 when a mishit but hard drive by a physician "blasted into the club-house door. This was seen for what it was, a thinly disguised attempt to reduce the number of surgical combatants."

After the match the surgeons scrub up before dinner but the physicians are "less punctilious in these matters. Few even bother to change their socks." Recordings become vague at this point - "the spirit is strong but the memory is weak"-but it has always been "an evening you could have brought your grandmother to without a qualm, though I fancy she would have liked a larger glass of port."

At this stage nostalgia and clichés overcome the recorders who by then have "secured for their mental picture galleries another precious canvas." The course is left to lick its wounds for another year, in the absence of other medical treatment. Good will reigns. On one occasion recently a surgeon was even seen in the darkness "taking the trouble to assist some poor physician to start his car." That may have been going too far, but had he doctored the petrol earlier? Friendly rivalry indeed. ... 